\title{
Selective Inhibition of Nuclear Factor- $\kappa B$ Activation After Hypoxia/Ischemia in Neonatal Rats Is Not Neuroprotective
}

\author{
EVELYN R.W. VAN DEN TWEEL, ANNEMIEKE KAVELAARS, MARIA S. LOMBARDI, FLORIS GROENENDAAL, \\ MICHAEL MAY, COBI J. HEIJNEN, AND FRANK VAN BEL
}

\begin{abstract}
Department of Neonatology [E.R.W.T., F.G., F.B.] and Laboratory for Psycho-Neuro-Immunology and Perinatology [E.R.W.T., A.K., M.S.L., C.J.H.], Wilhelmina Children's Hospital, University Medical Center Utrecht, 3584 EA Utrecht, The Netherlands; Department of Animal Biology [M.M.], University of Pennsylvania, Philadelphia, Pennsylvania 19104
\end{abstract}

\begin{abstract}
Activated nuclear factor- $\kappa \mathrm{B}(\mathrm{NF} \kappa \mathrm{B})$ has been shown to increase transcription of several genes that could potentially contribute to neuronal damage, such as proinflammatory cytokines, chemokines, and inducible nitric oxide synthase. The aim of our study was to investigate whether inhibition of $\mathrm{NF} \kappa \mathrm{B}$ activation could prevent hypoxia/ischemia (HI)-induced cerebral damage in neonatal rats. We used a cell permeable peptide (NEMO binding domain [NBD] peptide) that is known to prevent the association of the regulatory protein NEMO with IKK, the kinase that activates NF $\kappa$ B. Via this mechanism, the NBD peptide can specifically block the activation of $\mathrm{NF} \kappa \mathrm{B}$, without inhibiting basal $\mathrm{NF} \kappa \mathrm{B}$ activity. Cerebral $\mathrm{HI}$ was induced in neonatal rats by occlusion of the right carotid artery followed by $90 \mathrm{~min}$ of hypoxia $\left(\mathrm{FiO}_{2}=0.08\right)$. Immediately upon reoxygenation, as well as 6 and $12 \mathrm{~h}$ later, rats were treated with vehicle or NBD peptide $(20 \mathrm{mg} / \mathrm{kg}$ i.p.). Histologic analysis of brain damage was performed at $6 \mathrm{wk}$ after HI. To assess $\mathrm{NF} \kappa \mathrm{B}$ activation, electromobility shift assays (EMSAs) were performed on brain nuclear extracts obtained $6 \mathrm{~h}$ after reoxygenation. Increased $\mathrm{NF} \kappa \mathrm{B}$ activity could be shown at $6 \mathrm{~h}$ after $\mathrm{HI}$ in both hemispheres. Peripheral administration of NBD peptide prevented this HI-induced increase in $\mathrm{NF} \kappa \mathrm{B}$ activity in both hemispheres. Histologic analysis of long-term cerebral damage revealed that inhibition of $\mathrm{NF} \kappa \mathrm{B}$ activation by administration of NBD peptide at 0,6 , and $12 \mathrm{~h}$ after HI resulted in an increment of neuronal damage. In conclusion, our data suggest that inhibition of $\mathrm{NF} \kappa \mathrm{B}$ activation using NBD peptide early after HI increases brain damage in neonatal rats. (Pediatr Res 59: 232-236, 2006)
\end{abstract}

$\mathrm{P}_{\mathrm{n}}^{\mathrm{e}}$ erinatal $\mathrm{HI}$ is a common cause of neonatal mortality and morbidity. Long-term effects can be cerebral palsy and/or impaired neurodevelopmental outcome $(1,2)$. During HI and in particular upon reperfusion and reoxygenation, a cascade of potentially destructive pathways is activated eventually leading to neuronal cell death $(3,4)$.

Activation of the transcription factor $\mathrm{NF} \kappa \mathrm{B}$ regulates the production of pro- and anti-inflammatory cytokines, chemokines, and inducible nitric oxide synthase and of adhesion molecules, which together will promote apoptosis and neuronal cell death $(5,6)$. In resting cells, the heterodimeric $\mathrm{NF} \kappa \mathrm{B}$,

Received June 8, 2005; accepted September 21, 2005.

Correspondence: Frank van Bel, M.D., Ph.D., Department of Neonatology, Wilhelmina Children's Hospital/University Medical Center Utrecht, Room KE.04.123.1, P.O. Box 85090, 3508 AB Utrecht, The Netherlands; e-mail: F.vanBel@wkz.azu.nl. consisting of a p50 and a p65 protein, is retained in the cytoplasm through interaction with the inhibitory protein I $\kappa$ B. Activation of $\mathrm{NF} \kappa \mathrm{B}$ requires phosphorylation of $\mathrm{I} \kappa \mathrm{B}$ by the I $\kappa$-kinase complex, consisting of IKK $\alpha$, IKK $\beta$, and the regulatory protein NEMO. Phosphorylated I $\kappa \mathrm{B}$ will be ubiquitinated and degraded via the proteasome pathway. The free or activated NFKB can then translocate to the nucleus of the cell and will bind to the promoter sequences of many target genes (7).

Evidence of a role for $\mathrm{NF} \kappa \mathrm{B}$ activation in HI-induced cerebral damage comes from animal models. In NF $\kappa \mathrm{B}-\mathrm{p} 50$ knockout mice, neuronal damage was significantly reduced in an adult model of stroke by occlusion of the middle cerebral artery (8). Similarly, inhibition of the proteasome pathway with the proteasome inhibitor CVT-634 or PS519, leading to reduced $\mathrm{I} \kappa \mathrm{B}$ degradation and thereby reducing $\mathrm{NF} \kappa \mathrm{B}$ activation, has been reported to be neuroprotective as well $(9,10)$. Moreover, Stephenson et al. (11) suggested that the neuroprotective properties of antioxidant LY341122 are mediated by preventing the activation of $\mathrm{NF} \kappa \mathrm{B}$. In contrast, however, Hill et al. (12) described that inhibition of NF $\kappa \mathrm{B}$ with diethyldithiocarbamate increased brain damage $48 \mathrm{~h}$ after middle cerebral artery occlusion in rats.

A possible explanation for these conflicting effects of $\mathrm{NF} \kappa \mathrm{B}$ inhibition in models of HI-induced brain damage may be that most of the compounds used to prevent $\mathrm{NF} \kappa \mathrm{B}$ activation are inhibiting not only $\mathrm{NF} \kappa \mathrm{B}$ activation but also many other processes, such as protein degradation via the proteasome pathway. Interestingly, May et al. (13) reported selective inhibition of $\mathrm{NF} \kappa \mathrm{B}$ activation using a cell-permeable NBD peptide that blocks interaction of NEMO with the I $\kappa$-kinase complex. Via this mechanism, NBD peptide can prevent the activation of the IKK complex by proinflammatory mediators without inhibiting basal NF $\kappa$ B activity (13).

We investigated whether selective inhibition of the early HI-induced activation of $\mathrm{NF} \kappa \mathrm{B}$ with the NBD peptide provides neuroprotection in the 12-d-old rat pup. To investigate whether peripheral administration of NBD peptide indeed

Abbreviations: EMSA, electromobility shift assay; HI, hypoxia/ischemia; NBD peptide, NEMO binding domain peptide; NEMO, NFKB essential modifier; NF $\boldsymbol{\kappa} \mathbf{B}$, nuclear factor- $\kappa \mathrm{B}$ 
blocked HI-induced $\mathrm{NF} \kappa \mathrm{B}$ activation in the brain, we performed an EMSA for NF $\kappa \mathrm{B}$ using nuclear extract of the ipsiand contralateral hemisphere.

\section{MATERIALS AND METHODS}

Animal protocol. The Experimental Animal Committee of the UMC Utrecht approved all experimental protocols. Wistar rat pups of both sexes were exposed to a HI insult according to the model of Vannucci and Rice (14). In this study, 12-d-old rats were used because the developing cerebral cortex of the rat at that stage is comparable to that of the full-term human neonate $(15,16)$. The pups were anesthetized with halothane $(5.0 \%$ induction, $2.0 \%$ maintenance) in a mixture of $\mathrm{N}_{2} \mathrm{O}$ and $\mathrm{O}_{2}(1: 1)$. The right common carotid artery was exposed and ligated. The duration of the surgery was 5-7 min, after which the pups were allowed to recover for at least $60 \mathrm{~min}$. Subsequently, the pups were placed in an incubator with a constant temperature $\left(37^{\circ} \mathrm{C}\right)$, and humidity. HI was induced by lowering $\mathrm{Fio}_{2}$ to 0.08 in $\mathrm{N}_{2}$ for $90 \mathrm{~min}$. After the $\mathrm{HI}$ insult, the pups received treatment and were returned to their dams. Pups were killed by decapitation at $6 \mathrm{~h}$ after $\mathrm{HI}$ or by perfusion $48 \mathrm{~h}$ or $6 \mathrm{wk}$ after HI. After decapitation, the brain was removed, divided into two hemispheres and cerebellum, and stored at $-80^{\circ} \mathrm{C}$. Before perfusion rats were sedated with pentobarbital, subsequently intracardially perfused with $4 \%$ paraformaldehyde after which brains were removed, postfixed, and embedded in paraffin. Four rats underwent anesthesia and neck incision without carotid artery occlusion; these animals served as sham-operated controls. The animals were kept at room temperature with a light/dark cycle of $12 \mathrm{~h} / 12 \mathrm{~h}$ and had access to food and water ad libitum.

Study design. The animals that were subjected to HI were assigned to two groups. Animals randomly received an intraperitoneal injection with vehicle $(n=21)$ or NBD peptide $(n=19) 20 \mathrm{mg} / \mathrm{kg}$. The first dose was administered immediately after $\mathrm{HI}$ and subsequent doses at 6 and $12 \mathrm{~h}$. The NBD peptide was dissolved in DMSO $(40 \mathrm{mg} / \mathrm{mL})$ and subsequently diluted in PBS to a concentration of $1.2 \mathrm{mg} / \mathrm{mL}$ (13).

Histology. Six weeks after HI, $8-\mu \mathrm{m}$ thick sections of rat brains were cut approximately $-3.30 \mathrm{~mm}$ from the bregma and mounted on coated slides and stained with hematoxylin and eosin (Klinipath, Duiven, The Netherlands). The histopathology was scored in a blinded setup as described earlier (17). The regions CA1, CA2, CA3, and CA4 of the hippocampus and the dentate gyrus and six areas of the parietal cortex were scored for damage on a 4-point scale: 3 (normal), 2 (few neurons damaged), 1 (moderate number of neurons damaged), 0 (almost all neurons damaged and cystic infarction). The maximum cumulative score was 33 points and the minimal score was 0 . Subsequently, full-section images were captured with a Nikon D1 digital camera (Nikon, Tokyo, Japan) and processed in Adobe Photoshop 5.0 (Adobe Systems Inc., San Jose, CA). The size of the ipsi- and contralateral hemispheres was subsequently measured in arbitrary units, and the ratio of ipsilateral and contralateral hemisphere was calculated as a measure of neuronal damage.

Immunohistochemistry. Immunohistochemistry was performed on the brains of the rats $48 \mathrm{~h}$ after HI. Eight- microns thick coronal sections of paraffin-embedded brains were cut approximately -0.80 (A), -3.30 (B), and -6.60 (C) $\mathrm{mm}$ from the bregma and mounted on coated slides Sections were stained with mouse-anti-MAP2 (clone HM-2, Sigma Chemical Co., St. Louis, MO) followed by biotinylated horse- $\alpha$-mouse IgG (Vector Laboratories, Burlingame, CA) and visualization was performed using Vectastain $\mathrm{ABC}$ (Vector Laboratories) and diaminobenzidine, and sections were counterstained with hematoxylin.

Full-section images of the MAP2-stained sections were captured with a Nikon D1 digital camera and processed in Adobe Photoshop 5.0. The MAP2-positive and -negative areas of the ipsilateral hemisphere were determined in a blinded setup and the ratio of the MAP2-positive area to MAP2negative area was calculated as a measure of neuronal damage.

$\boldsymbol{E M S A}$. NF $\boldsymbol{k}$ B EMSAs were performed on nuclear extracts as described by Hickenbottom et al. (18) with minor modifications. Brain tissue was homogenized in lysis buffer $(50 \mathrm{mmol} / \mathrm{L}$ Tris, $5 \mathrm{mmol} / \mathrm{L}$ EDTA, $150 \mathrm{mmol} / \mathrm{L}$ $\mathrm{NaCl}$ ) supplemented with protease inhibitors (leupeptin $10 \mu \mathrm{g} / \mathrm{mL}$, pepstatin $5 \mu \mathrm{g} / \mathrm{mL}$, STI $10 \mu \mathrm{g} / \mathrm{mL}$, orthovanadate $1 \mathrm{mmol} / \mathrm{L}$, and $1 \mathrm{mmol} / \mathrm{L}$ PMSF). The homogenates were centrifuged at $13,000 \mathrm{rpm}$ for $15 \mathrm{~min}$, and pellets were used for extraction of nuclear protein. Pellets were homogenized in buffer $\mathrm{A}(10 \mathrm{mmol} / \mathrm{L}$ HEPES, $\mathrm{pH} 7.9,10 \mathrm{mmol} / \mathrm{L} \mathrm{KCl}, 1.5 \mathrm{mmol} / \mathrm{L}$ $\mathrm{MgCl}_{2}, 0.1 \mathrm{mmol} / \mathrm{L}$ EDTA, $0.1 \mathrm{mmol} / \mathrm{L}$ EGTA, $1 \mathrm{mmol} / \mathrm{L}$ DTT, and protease inhibitors), and after 15 min of incubation on ice, NP40 was added to a final concentration of $3.125 \%$. The mixture was vortexed and microfuged $\left(10,000 \mathrm{rpm}, 4^{\circ} \mathrm{C}\right)$ for $1 \mathrm{~min}$, and the nuclear pellet was resuspended in ice-cold hypertonic nuclear extraction buffer $(20 \mathrm{mmol} / \mathrm{L}$ HEPES, pH 7.9, $420 \mathrm{mmol} / \mathrm{L} \mathrm{NaCl}, 1.5 \mathrm{mmol} / \mathrm{L} \mathrm{MgCl}_{2}, 1 \mathrm{mmol} / \mathrm{L}$ EDTA, $1 \mathrm{mmol} / \mathrm{L}$ EGTA, $1 \mathrm{mmol} / \mathrm{L}$ DTT, and protease inhibitors), incubated on ice for $30 \mathrm{~min}$ and microfuged $(10,000 \mathrm{rpm})$ for $5 \mathrm{~min}$. The supernatant containing the nuclear extract was collected, and $5 \mu \mathrm{g}$ protein was incubated for $30 \mathrm{~min}$ at room temperature with ${ }^{32} \mathrm{P}$-end-labeled, double-stranded $\mathrm{NF} \kappa \mathrm{B}$ oligonucleotides (5' AGTTGAGGGGACTTTCCCAGGC). Binding reactions were performed in $20 \mu \mathrm{L}$ containing $25 \mathrm{mmol} / \mathrm{L}$ HEPES, $\mathrm{pH} 7.9,0.5 \mathrm{mmol} / \mathrm{L}$ EDTA, 0.5 $\mathrm{mmol} / \mathrm{L}$ EGTA, $0.5 \mathrm{mmol} / \mathrm{L}$ DTT, $5 \%$ glycerol, $1 \% \mathrm{NP}-40,50 \mathrm{mmol} / \mathrm{L} \mathrm{NaCl}$, $1 \mu \mathrm{g} \mathrm{plydt} / \mathrm{dC}$. To determine specificity of the EMSA, excess unlabeled oligonucleotides were added to some samples. Samples were separated on 5\% polyacrylamide gel with Tris/borate-EDTA running buffer and bound complexes were visualized by autoradiography. Optical density (OD) was analyzed using Chemidoc XRS with a G700 densitometer and Quantity One 1-D analysis software (Bio-Rad Laboratories, Hercules, CA).

Statistics. Data are presented as mean \pm SEM. SPSS software version 10 (SPSS, Chicago, IL) was used to calculate significance. Mann-Whitney $U$ tests were used for analysis of the difference between vehicle and NBD peptide-treated rats $6 \mathrm{wk}$ after HI. For analysis of the EMSA at $6 \mathrm{~h}$ and MAP2 at $48 \mathrm{~h}$, a Kruskal-Wallis test was used for analyzing differences between the sham and vehicle or NBD peptide-treated rats. Subsequently, Mann-Whitney $U$ tests were used for further analysis of the difference between vehicle and NBD peptide-treated rats. A $p$ value $<0.05$ was considered statistically significant.

\section{RESULTS}

Inhibition of $\mathbf{N F} \boldsymbol{\kappa} B$ activity. To investigate whether intraperitoneal administration of NBD peptide can prevent cerebral $\mathrm{NF} \kappa \mathrm{B}$ activation in the brain after exposure of $\mathrm{p} 12$ rat pups to HI, we performed EMSA using nuclear extracts of ipsi- and contralateral hemispheres. In a preliminary experiment, we analyzed $\mathrm{HI}$-induced NF $\kappa \mathrm{B}$ activity by EMSA at 1, 3, and $6 \mathrm{~h}$ after HI. Maximal NF $\kappa$ B activity was observed at $6 \mathrm{~h}$ after HI (data not shown). In subsequent experiments, we examined $\mathrm{NF} \kappa \mathrm{B}$ activity in nuclear extracts of ipsi- and contralateral hemispheres from sham-operated animals, vehicle-treated HI animals, and NBD peptide-treated $\mathrm{HI}$ animals obtained at $6 \mathrm{~h}$ after HI. The data in Figure 1 demonstrate that exposure of p12 rats to $\mathrm{HI}$ induces a significant increase in cerebral $\mathrm{NF} \kappa \mathrm{B}$ activity in both ipsi- and contralateral hemispheres at $6 \mathrm{~h}$ after HI. More importantly, the data also show that intraperitoneal administration of NBD peptide immediately after HI can almost completely prevent this $\mathrm{HI}$-induced increase in $\mathrm{NF} \kappa \mathrm{B}$ activity in the brain. Figure $1 B$ clearly shows that the EMSA is specific because the band disappears after addition of excess unlabeled oligonucleotides.

Short-term effects of NBD peptide. To determine the effect of NBD peptide administration at 0,6 , and $12 \mathrm{~h}$ after $\mathrm{HI}$ on early HI-induced neuronal damage, MAP2 staining was analyzed in three different areas of the ipsilateral hemisphere of vehicle-treated $(n=4)$ and NBD-treated $(n=4)$ rats $48 \mathrm{~h}$ after $\mathrm{HI}$ and of sham control rats $(n=4)$ (Figs. 2 and 3 ). The three sections were cut approximately -0.80 (A), -3.30 (B) and $-6.60(\mathrm{C}) \mathrm{mm}$ from the bregma. As depicted in Figure 2 and quantified in Figure 3, HI induced a significant $(p<0.05)$ loss of MAP2 staining in sections A and B. However, there were no significant differences in the HI-induced loss of MAP2 staining in NBD peptide-treated rats compared with vehicle-treated rats (Figs. 2 and 3).

Long-term effects of NBD peptide. At $6 \mathrm{wk}$ after exposure of p12 rats to HI, the combined neuropathology score of hippocampus and cortex of the ipsilateral hemisphere was significantly lower than the neuropathology score of contralat- 
A

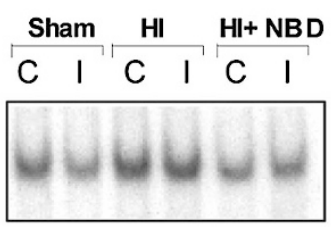

B

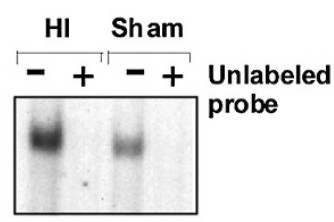

C

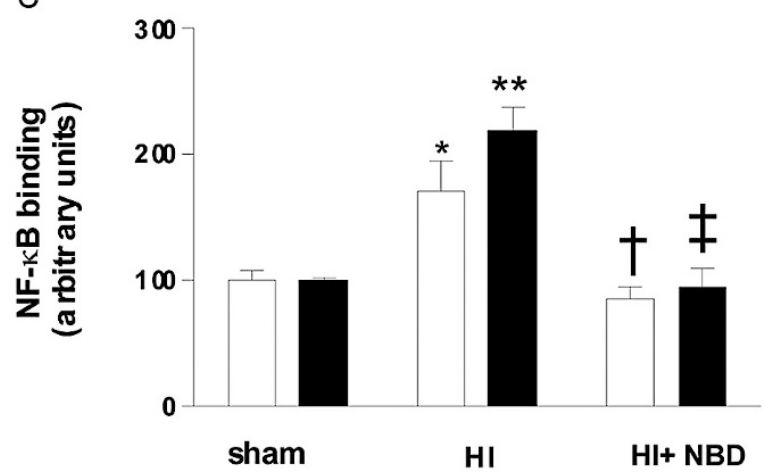

Figure 1. Inhibition of cerebral NF $\kappa$ B DNA binding activity by NBD peptide: Nuclear extracts were prepared from ipsi- and contralateral hemispheres from sham control rats $(n=4)$, and from vehicle-treated $(n=4)$ or NBD peptide-treated rats $(n=4)$ at $6 \mathrm{~h}$ after $\mathrm{HI}$. NF $\kappa \mathrm{B}$ activity in the nuclear extracts was determined by EMSA using an oligonucleotide probe containing the NF $\mathrm{KB}$ binding site. (A) Representative example of the autoradiograph after EMSA. (B) Specificity of the EMSA determined by adding excess unlabeled oligonucleotides. (C) Data represent mean and SEM and are expressed as arbitrary density units. Contralateral (open columns), ipsilateral (filled columns). ${ }^{*} p<0.05$ vs sham; ${ }^{* *} p<0.01$ vs sham; $\dagger p<0.05$ vs HI; $\ddagger p<0.01$ vs HI.

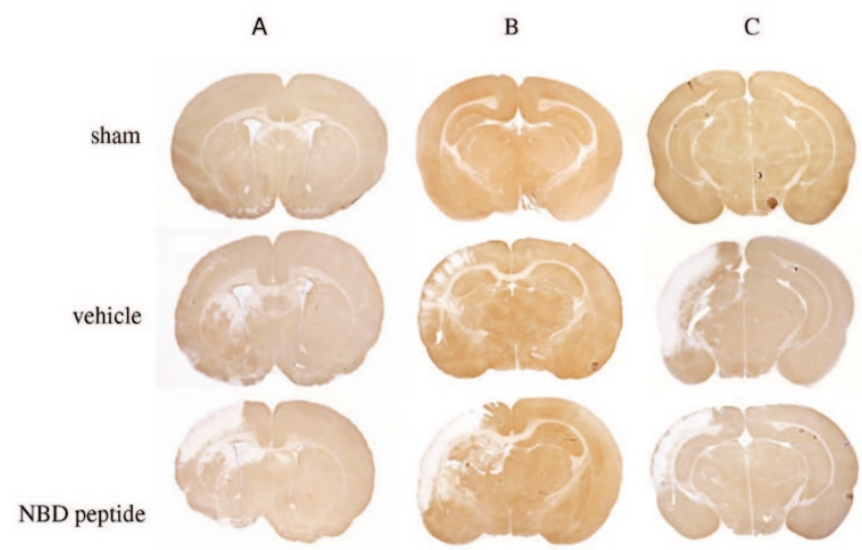

Figure 2. Representative example of MAP2 staining $48 \mathrm{~h}$ after HI, in vehicle- and NBD-treated rats and in sham-treated rats. Immunohistochemistry for MAP2 was performed on 8- $\mu \mathrm{m}$ thick coronal sections cut approximately $-0.80(A),-3.30(B)$ and $-6.60(C) \mathrm{mm}$ from the bregma.

eral hemisphere of vehicle-treated animals (Fig. 4A, $p<$ 0.01 ). Treatment with NBD peptide at 0,6 , and $12 \mathrm{~h}$ after HI did not reduce long-term neuronal damage, but rather resulted in an even lower combined neuropathology score in the ipsilateral hemisphere $(p<0.05)$. Treatment with NBD peptide did not have any effect on the combined neuropathology score in the contralateral hemisphere (Fig. 4A), indicating that the peptide is not neurotoxic by itself.

Analysis of the ratio of the area of the ipsilateral/ contralateral hemisphere demonstrated a significant reduction in the ratio of both vehicle- and NBD-treated rats after HI compared with sham-treated animals $(p<0.01)$ (Fig. $4 B)$. The ratio of the ipsi/contralateral hemispheres of NBD-treated animals was significantly $(p<0.05)$ lower than that of vehicle-treated animals.

\section{DISCUSSION}

The goal of the present study was to investigate whether selective inhibition of $\mathrm{NF} \kappa \mathrm{B}$ activation would reduce neuronal damage after neonatal HI. We applied the specific NF $\kappa \mathrm{B}$ inhibitory NBD peptide, originally described by May et al. (13). The NBD peptide blocks the interaction of NEMO with $\operatorname{IKK} \alpha, \operatorname{IKK} \beta$ resulting in an inability to phosphorylate $\mathrm{I} \kappa \mathrm{B}$ and to subsequently activate NFKB (13). This peptide has been shown to reduce the inflammatory response in various models of peripheral inflammation. Using EMSA, we show here that peripheral administration of NBD peptide at a dose of $20 \mathrm{mg} / \mathrm{kg}$ can completely prevent HI-induced activation of $\mathrm{NF} \kappa \mathrm{B}$ in the brain. However, inhibition of $\mathrm{NF} \kappa \mathrm{B}$ activation by treatment with the NBD peptide during the first $24 \mathrm{~h}$ after HI did not reduce but rather increased neuronal damage as determined at 6 wk after the insult.

Apart from proinflammatory molecules, $\mathrm{NF} \kappa \mathrm{B}$ can also induce expression of antiapoptotic factors, including Bcl-2 and Bcl-x. Moreover, NF $\kappa \mathrm{B}$ can increase the expression of neurotrophins (e.g. nerve growth factor) and superoxide dismutase, which all could contribute to neuronal survival (19). Indeed, in vitro studies in cultures of rat hippocampal neurons (19-21) and studies in transgenic mice (22) have shown that $\mathrm{NF} \kappa \mathrm{B}$-signaling in brain tissue is important for neuronal survival, synaptic plasticity, and the prevention of apoptotic cell death. By inhibiting the HI-induced increase in $\mathrm{NF} \kappa \mathrm{B}$ activity with NBD peptide, without interfering with the basal activity, we assumed that the deleterious effects of $\mathrm{NF} \kappa \mathrm{B}$ activation would have been prevented while the neuroprotective activity of $\mathrm{NF} \kappa \mathrm{B}$ might have been maintained. However, our data suggest that this was not the case.

In earlier publications, inhibition of $\mathrm{NF} \kappa \mathrm{B}$ activation after middle cerebral artery occlusion has been described to decrease neuronal damage $(9,10,12,23)$. How can we explain the results of several studies showing neuroprotection after $\mathrm{NF} \kappa \mathrm{B}$ inhibition? One possible explanation is that in these studies $\mathrm{NF} \kappa \mathrm{B}$ was inhibited by drugs with known other pharmacological effects as well. For example, CVT-634 and PS519 are proteasome inhibitors that reduce $\mathrm{NF} \kappa \mathrm{B}$ activation by inhibition of the degradation of $\mathrm{I} \kappa \mathrm{B}$. However, inhibition of the proteasome pathway may also alter the availability of other proteins that are involved in neuronal damage. $N$-acetylcysteine inhibits $\mathrm{NF} \kappa \mathrm{B}$ activation but also has antioxidant activity, which may contribute to neuroprotection (23). Therefore, it is difficult to conclude from these studies whether the observed neuroprotective effects are mediated via inhibition of $\mathrm{NF} \kappa \mathrm{B}$ alone or are also dependent on the additional effects of these drugs. 

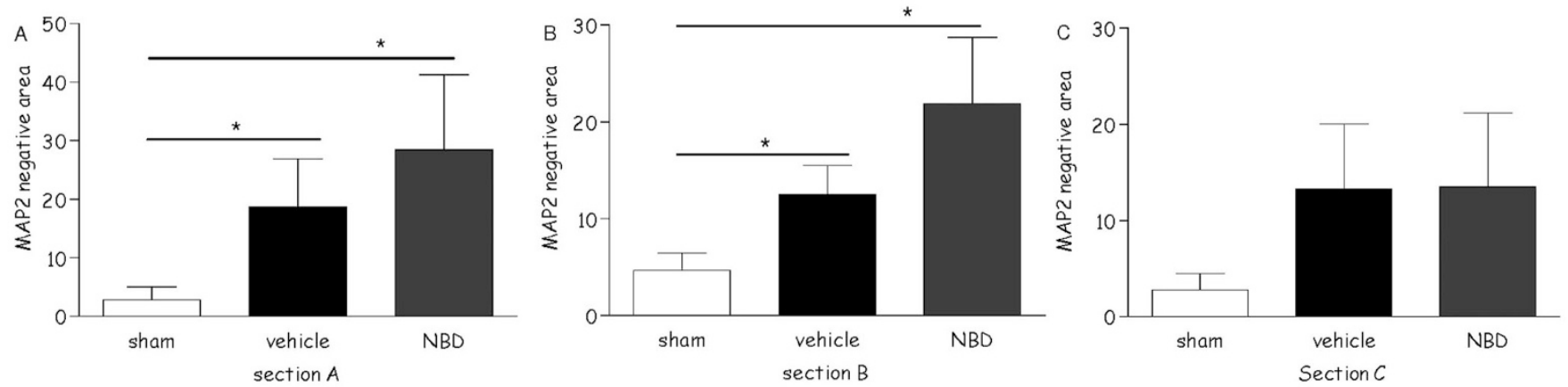

Figure 3. Short-term outcome after treatment with NBD-peptide of sham rats $(n=4)$, vehicle-treated $(n=4)$, and NBD-treated $(n=4)$ rats. Immunohistochemistry was performed as described in the legend to Figure 2. The MAP2-positive and -negative areas of the ipsilateral hemispheres were determined, and the ratio of the MAP2-negative area to MAP2-positive area was calculated as a measure of neuronal damage. Data are expressed as the mean percentage of MAP-negative area and SEM. *: $p<0.05$. (A) $-0.80 ;(B)-3.30 ;(C)-6.60 \mathrm{~mm}$ from bregma.

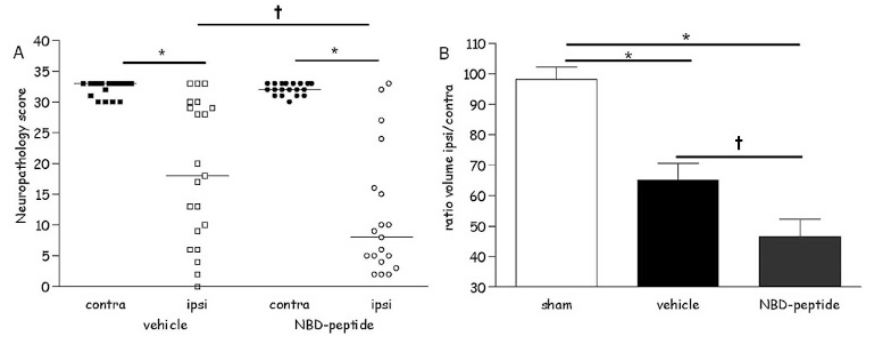

Figure 4. Long-term outcome after treatment with NBD peptide: Rats were treated with vehicle $(n=21)$ or NBD peptide $(n=19)(20 \mathrm{mg} / \mathrm{kg})$ at 0,6 , and $24 \mathrm{~h}$ after HI. Six weeks later, the cumulative neuropathology score was determined. Cerebral damage was scored in six areas of the cortex and the CA1, CA2, CA3, and CA4 of the hippocampus and dentate gyrus on a 4-point scale (range, $0-3$ ), resulting in a maximal score of 33. In addition, the ipsiand contralateral areas were measured (see Methods section). (A) The combined ipsilateral score for each individual animal. $(B)$ Cerebral damage expressed by the ratio of the area of the ipsilateral and contralateral side. (Data represent mean and SEM.) $* p<0.01, \dagger p<0.05$.

An alternative, perhaps more plausible explanation may be that inhibition of $\mathrm{NF} \kappa \mathrm{B}$ activity in the periphery is neuroprotective, whereas inhibition of $\mathrm{NF} \kappa \mathrm{B}$ in the brain enhances neuronal damage. Indeed, treatment with the proteasome inhibitor PS519, which does not penetrate the blood-brain barrier, resulted in a marked reduction in infarction size and improvement of neuronal recovery after transient focal cerebral HI (9). The neuroprotective effect of PS519 in these studies has been attributed to a considerable reduction in both neutrophil and macrophage infiltration into the brain (9). In line with this hypothesis, Hill et al. (12) have shown that the $\mathrm{NF} \kappa \mathrm{B}$ inhibitor diethyldithiocarbamate, which penetrates the blood-brain barrier, induced increased neuronal death in a transient occlusion model of the middle cerebral artery. Because the above-mentioned studies were performed in the adult animal, it remains to be confirmed that inhibition of $\mathrm{NF} \kappa \mathrm{B}$ activity in the periphery is also neuroprotective in neonatal animals. In addition, it should be noted that we cannot exclude that the reduction in NFkB activity that we observed in the brain of animals exposed to $\mathrm{HI}$ and treated with NBD peptide is not caused by a direct effect of the peptide in the brain. It is possible that the peripheral administration of results in direct inhibition of $\mathrm{NF} \kappa \mathrm{B}$ in cells in the periphery, e.g. inflammatory cells, and that the reduced $\mathrm{NF} \kappa \mathrm{B}$ activity in the brain occurs secondary to the reduction of peripheral NF $\kappa \mathrm{B}$ activity. This does not seem to be the most plausible explanation, however, because it has been shown that inhibition of inflammatory activity in the periphery can protect against HI-induced brain injury. For example, Hudome et al. (24) have shown that depletion of animals from neutrophils protects against brain injury in this model.

There is evidence that activation of $\mathrm{NF} \kappa \mathrm{B}$ may last for days after the insult $(10,25)$. Therefore, we cannot exclude the possibility that treatment with NBD peptide for a more prolonged period of time could be neuroprotective.

In summary, the present study showed that $\mathrm{NF} \kappa \mathrm{B}$ is not an attractive target for development of neuroprotective strategies. We cannot exclude the possibility that selective inhibition of peripheral $\mathrm{NF} \kappa \mathrm{B}$ activity would have beneficial effects in models of HI-induced brain damage. However, it should be considered that the blood- brain barrier of the neonate might be less functional than that of adults, especially after severe HI. Therefore, it is questionable whether it will be possible to develop a drug that selectively inhibits $\mathrm{NF} \kappa \mathrm{B}$ activity in the periphery for prevention of HI-induced brain damage in neonates.

\section{REFERENCES}

1. Dilenge ME, Majnemer A, Shevell MI 2001 Long-term developmental outcome of asphyxiated term neonates. J Child Neurol 16:781-792

2. Simon NP 1999 Long-term neurodevelopmental outcome of asphyxiated newborns. Clin Perinatol 26:767-778

3. Peeters C, van Bel F 2001 Pharmacotherapeutical reduction of post-hypoxicischemic brain injury in the newborn. Biol Neonate 79:274-280

4. Hamrick SE, Ferriero DM 2003 The injury response in the term newborn brain: can we neuroprotect? Curr Opin Neurol 16:147-154

5. O'Neill LA, Kaltschmidt C 1997 NF-kappa B: a crucial transcription factor for glial and neuronal cell function. Trends Neurosci 20:252-258

6. Siebenlist U, Franzoso G, Brown K 1994 Structure, regulation and function of NF-kappa B. Annu Rev Cell Biol 10:405-455

7. Matthews JR, Hay RT 1995 Regulation of the DNA binding activity of NF-kappa B. Int J Biochem Cell Biol 27:865-879

8. Schneider A, Martin-Villalba A, Weih F, Vogel J, Wirth T, Schwaninger M 1999 NF-kappaB is activated and promotes cell death in focal cerebral ischemia. Nat Med 5:554-559

9. Phillips JB, Williams AJ, Adams J, Elliott PJ, Tortella FC 2000 Proteasome inhibitor PS519 reduces infarction and attenuates leukocyte infiltration in a rat model of focal cerebral ischemia. Stroke 31:1686-1693

10. Buchan AM, Li H, Blackburn B 2000 Neuroprotection achieved with a novel proteasome inhibitor which blocks NF-kappaB activation. Neuroreport 11:427-430

11. Stephenson D, Yin T, Smalstig EB, Hsu MA, Panetta J, Little S, Clemens J 2000 Transcription factor nuclear factor-kappa $\mathrm{B}$ is activated in neurons after focal cerebral ischemia. J Cereb Blood Flow Metab 20:592-603

12. Hill WD, Hess DC, Carroll JE, Wakade CG, Howard EF, Chen Q, Cheng C, Martin-Studdard A, Waller JL, Beswick RA 2001 The NF-kappaB inhibitor dieth- 
yldithiocarbamate (DDTC) increases brain cell death in a transient middle cerebral artery occlusion model of ischemia. Brain Res Bull 55:375-386

13. May MJ, D'Acquisto F, Madge LA, Glockner J, Pober JS, Ghosh S 2000 Selective inhibition of NF-kappaB activation by a peptide that blocks the interaction of NEMO with the IkappaB kinase complex. Science 289:1550-1554

14. Rice JE 3rd Vannucci RC, Brierley JB 1981 The influence of immaturity on hypoxic-ischemic brain damage in the rat. Ann Neurol 9:131-141

15. Hagberg H, Ichord R, Palmer C, Yager JY, Vannucci SJ 2002 Animal models of developmental brain injury: relevance to human disease. A summary of the panel discussion from the Third Hershey Conference on Developmental Cerebral Blood Flow and Metabolism. Dev Neurosci 24:364-366

16. Romijn HJ, Hofman MA, Gramsbergen A 1991 At what age is the developing cerebral cortex of the rat comparable to that of the full-term newborn human baby? Early Hum Dev 26:61-67

17. van den Tweel ER, van Bel F, Kavelaars A, Peeters-Scholte CM, Haumann J, Nijboer CH, Heijnen CJ, Groenendaal F 2005 Long-term neuroprotection with 2-iminobiotin, an inhibitor of neuronal and inducible nitric oxide synthase, after cerebral hypoxia-ischemia in neonatal rats. J Cereb Blood Flow Metab 25:67-74

18. Hickenbottom SL, Grotta JC, Strong R, Denner LA, Aronowski J 1999 Nuclear factor-kappaB and cell death after experimental intracerebral hemorrhage in rats. Stroke 30:2472-2477
19. Tamatani M, Mitsuda N, Matsuzaki H, Okado H, Miyake S, Vitek MP, Yamaguchi A, Tohyama M 2000 A pathway of neuronal apoptosis induced by hypoxia/ reoxygenation: roles of nuclear factor-kappaB and Bcl-2. J Neurochem 75:683-693

20. Culmsee C, Siewe J, Junker V, Retiounskaia M, Schwarz S, Camandola S, E Metainy S, Behnke H, Mattson MP, Krieglstein J 2003 Reciprocal inhibition of p53 and nuclear factor-kappaB transcriptional activities determines cell survival or death in neurons. J Neurosci 23:8586-8595

21. Yu Z, Zhou D, Bruce-Keller AJ, Kindy MS, Mattson MP 1999 Lack of the p50 subunit of nuclear factor-kappaB increases the vulnerability of hippocampal neurons to excitotoxic injury. J Neurosci 19:8856-8865

22. Kassed CA, Willing AE, Garbuzova-Davis S, Sanberg PR, Pennypacker KR 2002 Lack of NF-kappaB p50 exacerbates degeneration of hippocampal neurons after chemical exposure and impairs learning. Exp Neurol 176:277-288

23. Carroll JE, Howard EF, Hess DC, Wakade CG, Chen Q, Cheng C 1998 Nuclear factor-kappa $\mathrm{B}$ activation during cerebral reperfusion: effect of attenuation with N-acetylcysteine treatment. Brain Res Mol Brain Res 56:186-191

24. Hudome S, Palmer C, Roberts RL, Mauger D, Housman C, Towfighi J 1997 The role of neutrophils in the production of hypoxic-ischemic brain injury in the neonatal rat. Pediatr Res 41:607-616

25. Mattson MP, Culmsee C, Yu Z, Camandola S 2000 Roles of nuclear factor kappaB in neuronal survival and plasticity. J Neurochem 74:443-456 